\title{
STRESS REGULATES THE LYMPHOCYTE HOMING RECEPTOR CD62L (L-SELECTIN)
}

\author{
Gisele Gus Manfro',2, Carlos Alexandre Netto', Mark Pollack², \\ Kelin Maggioni Mezzomo3, Frederic Preffer², Richard Kradin²
}

\begin{abstract}
Based on a previous study showing that panic disorder patients had increased expression of naïve phenotype lymphocytes (CD45RA+ and CD62L+), increased plasma cortisol, as well as decreased interleukin2 (IL-2) producion, we hypothesized that changes in the percentage of expression of these lymphocyte surface molecules could be related to the substances released by the hypothalamic-pituitary-adrenal (HPA) axis and possibly associated to panic disorder (cortisol, IL-2, serotonin and epinephrine). In order to study the altered expression, blood mononuclear cells of normal volunteers were stimulated with mitogen, in the presence of dexamethasone, IL-2, serotonin and epinephrin. CD62L is decreased by IL-2 in vitro. Serotonin and epinephrine did not promote changes in the expression of these surface molecules. The results of the ex vivo study are in agreement with a previous clinical study with panic patients. It could be suggested that stress is responsible for certain immunologic dysfunctions and new studies should be conducted.
\end{abstract}

KEY WORDS: corticosteroids, interleukin-2, lymphocyte migration, adhesion molecules, panic disorder.

\section{Regulação do receptor de alojamento linfocitário CD62L (L-selectina) pelo estresse}

RESUMO - Baseado em estudo prévio que demonstrou que os pacientes com transtorno do pânico apresentavam aumento na porcentagem de expressão de linfócitos com fenótipo virgem (CD45RA+ e CD62L+), aumento no cortisol plasmático, assim como diminuição na produção de interleucinas, foi sugerido que as alterações na porcentagem de expressão dessas moléculas de superfície dos linfócitos poderia estar relacionada com a liberação de substâncias pelo eixo hipotálamo-hipófise-adrenal (HHA) e possivelmente associada ao transtorno do pânico (cortisol, IL-2, serotonina e epinefrina). Com o objetivo de estudar essas alterações, células mononucleares do sangue periférico de voluntários normais foram estimuladas com mitógeno, na presença de dexametasona, IL-2, serotonina e epinefrina. A expressão de CD62L "in vitro" é diminuida com IL-2. Serotonina e epinefrina não promovem alterações na expressão dessas moléculas de superfície. Os resultados desse estudo "in vitro" estão de acordo com o estudo clínico prévio com pacientes com transtorno do pânico. Podese sugerir que o estresse é responsável por algumas disfunções imunológicas e novos estudos devem ser delineados para testar essa hipótese.

PALAVRAS-CHAVE: corticosteróides, interleucina-2, migração linfocitária, moléculas de adesão, transtorno do pânico.

The importance of the interactions between the nervous and the immune system has been the subject of a number of critical reviews ${ }^{1}$. These interactions are expressed in many disorders and there is an ongoing literature suggesting abnormalities of the immune function in mentally ill patients, including panic disorder. Patients with panic disorder suffer from recurrent and frequently disabling panic attacks, as well as anticipatory anxiety accompanied by catastrophic cognitions and physiological changes that resemble a "fight or flight" response ${ }^{2}$. Panic attacks are accompanied by activation of the autonomic nervous system and the hypothalamicpituitary-adrenal (HPA) axis ${ }^{2,3}$. Changes in the activation of the immune system can be observed as a consequence of the effects of neuroendocrine mediators generated during panic anxiety ${ }^{4}$. Women with panic disorder showed increased serum levels of soluble interleukin-2 receptors (IL-2R) and increased natural killer (NK) activities ${ }^{5,6}$. However, these findings are not supported by other reports that have demonstrated normal or diminished im-

\footnotetext{
'Departamento de Bioquímica, Universidade Federal do Rio Grande do Sul; Serviço de Psiquiatria do Hospital de Clínicas de Porto Alegre, Porto Alegre RS, Brazil; ${ }^{2}$ Immunopathology Unit of the Departament of Pathology and the Psychopharmacology Unit of the Department of Psychiatry, Massachusetts General Hospital, Harvard Medical School, Boston, MA, USA; ${ }^{3}$ Departamento de Psiquiatria e Medicina Legal, Universidade Federal do Rio Grande do Sul, Brazil, Porto Alegre RS, Brasil.
}

Received 6 April 2002, received in final form 8 August 2002. Accepted 29 August 2002.

Dra. Gisele Gus Manfra - Luiz Manoel Gonzaga, 630/11 - 90470-280 Porto Alegre RS, Brasil. FAX: 5133289234.

E-mail: gmanfro@portoweb.com.br 
mune function in panic disorder patient ${ }^{7,8}$. Panic disorder is also associated to changes in serotonergic and adrenergic system. Many clinical trials have shown the efficacy of serotonergic reuptake inhibitor in the treatment of panic disorder, suggesting that this neurotransmitter is associated to panic disorder ${ }^{9}$. Lines of investigation also suggest that the central noradrenergic system might be "hiperactive" in panic disorders patients as demonstrated by sudies with the alpha-2 receptor ${ }^{10}$.

T-lymphocytes are motile cells that normally migrate between organized lymphoid tissues, the circulating blood and peripheral non-lymphoid organs, reflecting highly specific adhesive interactions of receptor-ligand pairs on lymphocytes and vessel walls ${ }^{11}$. CD62L is one of a family of adhesive proteins designated as "selectins". It is present on the surface membrane of all leukocytes, where it plays a critical role in the early weak adhesive "rolling" interactions between white cells and vascular wall ${ }^{11}$. Lselectin mediates homing of naïve T-lymphocytes (CD45RA+) to the high endothelial venules of peripheral lymph nodes and serve as the primary site of binding for circulating lymphocytes into organized peripheral lymphoid tissues ${ }^{12}$.

We have recently demonstrated that panic disorder patients showed enrichment for naïve T lymphocytes (CD45RA) and increased expression of CD62L compared to controls, as well as increased plasma cortisol $^{13}$. The aim of this study is to evaluate if peripheral blood lymphocytes of normal volunteers altered their surface membrane expression of molecules that characterize the homing and activation of the T-cells in the presence of substances related to stress in order to investigate if these substances could be involved in the phenotypic changes in L-selectins expression noticed in the previous clinical study.

\section{METHOD}

Peripheral blood was drawn by venipuncture into tubes with acid citrate dextrose from normal volunteers who did not meet any diagnosis for major psychiatric disorder and were medically healthy and medication free. The study protocol was approved by the Human Studies Committee of the Massachusetts General Hospital.

The blood mononuclear cells were purified on a Ficoll-Hypaque density gradient and stained with a panel of fluorescein isothiocyanate conjugated antibodies (FITC): anti-CD25 (anti-IL-2R) ${ }^{14}$, anti-CD45RO (DAKO-UCHL-1), anti-CD45RA (anti-Leu 18), antiCD62L (anti-Leu 8) ${ }^{15}$ and phycoerithrin conjugated antibody (PE): anti-CD3 ${ }^{16}$ for 30 minutes at $4^{\circ} \mathrm{C}$. After the staining, cells were washed twice in phosphate buffered saline (PBS), pH 7.3 and fixed in $2 \%$ paraformaldehyde for 5 minutes. Subsequent analysis was performed in a FACS 440 cytofluorimeter (Becton Dickinson, Mountain View, Ca). The forward scatter (FCS) and side light scatter (SSC) characteristics were used to eletronically gate the lymphocyte population.

Mononuclear cells $\left(6 \times 10^{6}\right.$ cells) were divided into 4 groups ( $1.5 \times 10^{6}$ cells in each one) and stimulated with phytohemagglutinin (PHA, $5 \mathrm{ug} / \mathrm{ml}$ ) in RPMI 1640 supplemented with $10 \%$ fetal calf serum, $1 \mathrm{M}$ Hepes, $2 \mathrm{mM} / \mathrm{L}$ glutamine (all from GIBCO) and $10 \mathrm{mg} /$ $\mathrm{ml}$ gentamicine (SIGMA) in the presence of dexamethasone $\left(10^{-6} \mathrm{M}\right.$, SIGMA), IL-2 (100 Cetus Unit), epinephrine $10^{-7} \mathrm{M}$ and serotonin $10^{-4} \mathrm{M}$ for up to 10 days in a humidified chamber with $95 \%$ air and $5 \%$ carbon dioxide. The doses of dexamethasone, epinephrine and serotonin were based on the literature ${ }^{17}$ and previous experiment done in our laboratory and represent the increase of cortisol generated during stress and the adrenergic stress respectively ${ }^{17,18}$. Cells were subsequently harvested at 3 day intervals, washed and stained with the same FITC and PE conjugated monoclonal antibodies that react with the selected cell surface antigen.

Data were analysed by one way Analysis of Variance, ANOVA, followed by the Duncan multiple range test when indicated, using a statistical package, SPSS version 6.0, for windows platform run in PCcompatible personal computer.

\section{RESULTS}

After 3 days of PHA stimulation, an increased expression of CD 25 was observed. As predicted, cells that were cultured in the presence of IL-2 showed increased expression of the IL-2 receptor at days $3(\mathrm{~F}=45.75$; $\mathrm{p}<0.001), 6(\mathrm{~F}=224.19 ; \mathrm{p}<0.0001)$ and $9(\mathrm{~F}=6,66$; $p<0.01)$. The addition of dexamethasone produced downregulation of $C D 25$ expression $(F=45.75$; $\mathrm{p}<0.0001$ ), but not in the presence or IL-2. (Fig 1).

The results demonstrated that 3 days after treatment with IL-2 there was diminished expression of the percentage of the surface molecule CD62L $(F=5.17 ; p<0.01)$. Such effect was sustained during the ten days of the experiment $(F=13.58 ; p<0.001$ at day 6 and $F=21.44 ; p<0.0001$ at day 9). Cells stimulated with PHA and cultured with dexamethasone showed no significant changes in the expression of this molecule (Fig 2).

After 3 days in culture with dexamethasone or IL2 , cells showed no changes in the percentage of expression of CD45RA ( $F=0.10 ; p>0.05)$. By day 6 , cells stimulated with PHA in the presence of IL-2 showed diminished CD45RA expression $(F=4.98 ; p<0.01)$. 


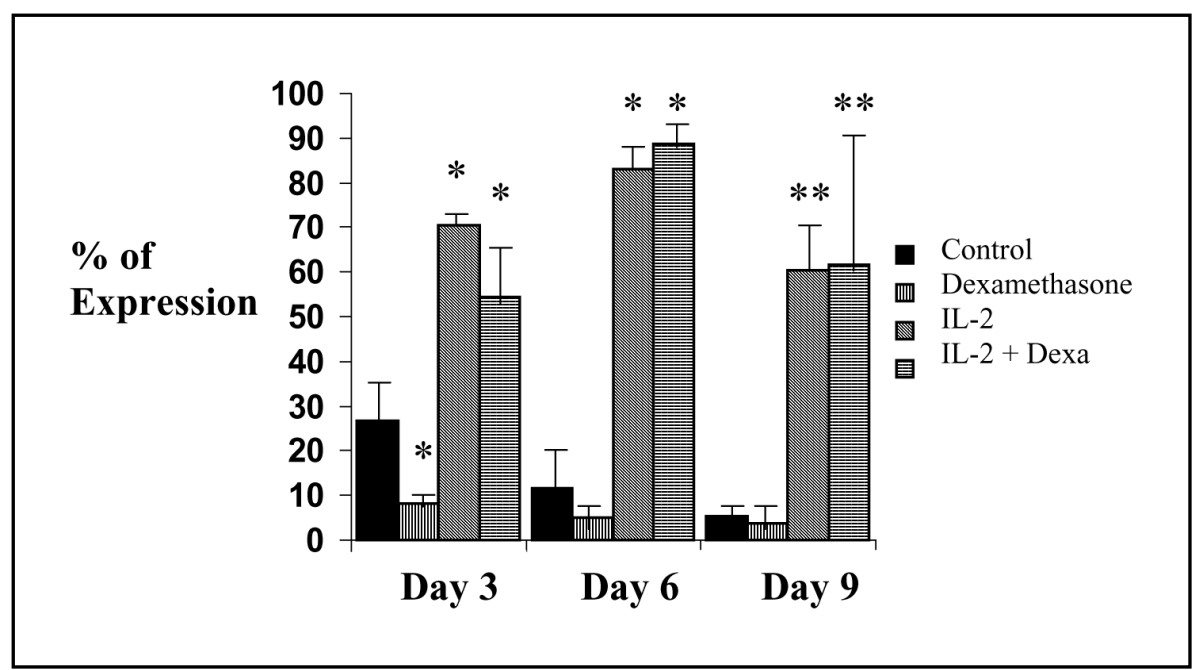

Fig 1. Surface membrane expression of CD 25 (IL-2R). Peripheral blood lymphocytes were activated with PHA $(5 \mathrm{mg} / \mathrm{ml})$ and cultured in the presence of 100 units of human recombinant IL-2, dexamethasone (Dexa: $10^{-6} \mathrm{M}$ ). Cells were harvested at intervals up to day 10 and examined after immunostaining for membrane expression of $C D 25 .{ }^{*} p<0.0001 ;{ }^{* *} p<0.01$ as compared to the control group.

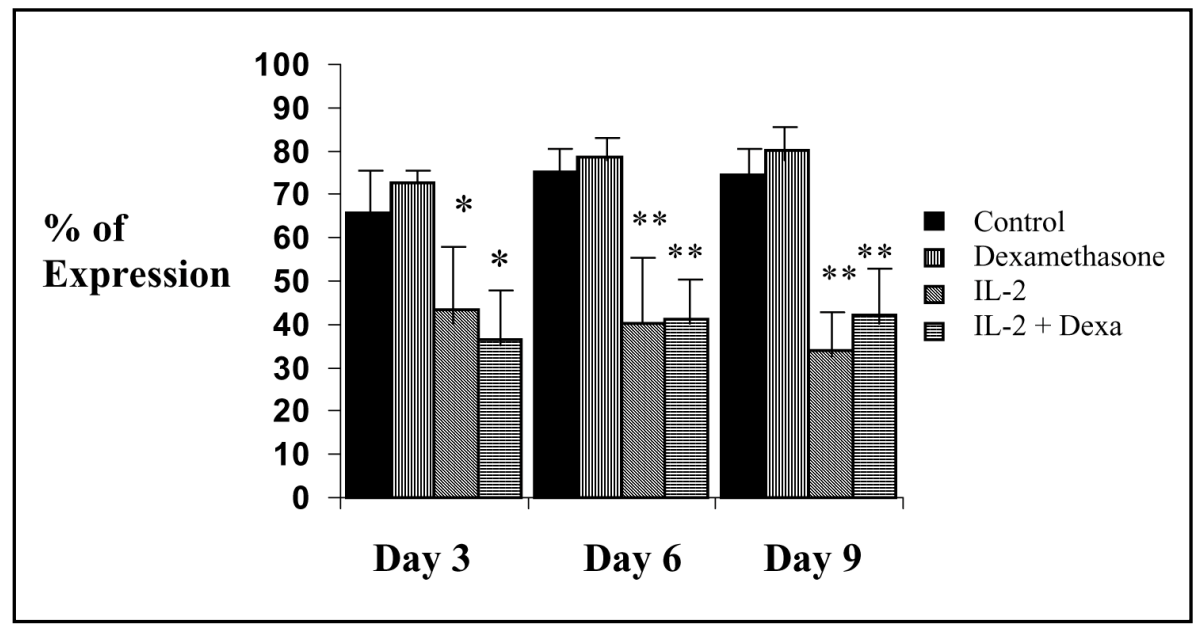

Fig 2. Surface membrane expression of CD $62 \mathrm{~L}$ ( $L$ selectin). Peripheral blood lymphocytes were activated with PHA (5mg/ml) and cultured in the presence of 100 units of human recombinant $/ \mathrm{L}-2$, dexamethasone (Dexa: $10^{-6} \mathrm{M}$ ). Cells were harvested at intervals up to day 10 and examined after immunostaining for membrane expression of CD 62L. ${ }^{*} p<0.001 ;{ }^{* *} p<0.0001$ as compared to the controls group.

The addition of IL-2 to the cultured of cells stimulated with PHA produced no modification in the expression of $C D 45 R O$, the memory T cells, at day 3 $(F=1.24 ; p>0.05)$ and at day $6(F=1.74 ; p>0.05)$. By day 9 , on the other hand, cells stimulated with PHA and cultured with IL-2, showed increased expression of $C D 45 R O(F=5.19 ; p<0.01)$. The addition of dexamethasone to the culture of cells stimulated with PHA produced no changes in the expression of the isoforms CD45RA and CD45RO.

Interestingly, the addition of epinephrine and serotonin did not change the expression of the molecules studied (CD25, CD62L, CD45RA and CD45RO). Also, they did not interfere with the changes in the expression of these molecules, promoted by IL-2, suggesting that these amines are probably not involved on the expression of CD25, CD45RA, CD45RO and CD62L observed in the experiment.

\section{DISCUSSION}

The aim of this study was to evaluate the effects of dexamethasone, IL-2, serotonin and epinephrine (substances that have been associated to panic disorder and to the HPA axis) on the expression of lymphocytes surface molecules expression (CD25, CD45RA, CD45RO, CD62L). Based upon the results of a previous clinical study demonstrating that panic disorder patients showed increased expression of 
CD62L+ and CD45RA+ lymphocytes as compared to controls ${ }^{13}$, we studied the expression of these surface lymphocytes molecules "in vitro".

Cells that were stimulated with PHA in the presence of IL-2 showed differences in the expression of $C D 25$ and $C D 62 L$ at day 3, but the changes in the expession of CD45RA and CD45RO could only be observed later, at days 6 and 9 . This happens because the expression of CD25 (IL-2 receptor) increased soon after the lymphocytes were stimulates with PHA once small concentrations of IL-2 are enough for DNA synthesis and for stimulating cell cicle development ${ }^{19}$. Steroids such as dexamethasone could inhibit IL-2 secretion ${ }^{20}$, but also lead to cell death by apoptosis ${ }^{21}$, and this could explain why the diminished expression of CD25 after stimulation with dexamethasone occurred only at day 3 and no changes were observed at days 6 and 9 .

Cells that were stimulated in the presence of IL-2 showed decreased expression of CD62L. Once the lymphocytes were activated, they lose the expression of L-selectin, the adhesion molecule that is present in naïve lymphocytes responsible for their migration to lymphonodes ${ }^{11}$. The lost of L-selectin is accompanied by the increased expression of other integrins such as LFA- 1 and $\alpha 1 \beta 2$ that make the memory lymphocytes migrate to the target-organs ${ }^{11}$. This change in the L-selectin surface molecules is inversely related to the expression of CD25 (IL-2R). As it was described before, changes in the expession of CD45RA and CD45RO could be observed at days 6 and 9. It is known that activated T-cell lose the expression of CD45RA very slowly and those T-cells could present both isophorm (CD45RA and CD45RO) at the same time $^{22}$. At day 6 , cells stimulated with IL-2 showed decreased of CD45RA and at day 9 they increased the expession of the isomorph CD45RO.

However, other substances implicated in the HPA axis, as the amines serotonin and epinephrine, could not change the expression of these studied surface molecule in cells stimulated with PHA. This result is consistent with previous studies showing that vasoconstrictor such as epinephrine has no influence on adhesion molecule expression ${ }^{23}$. On the other hand, some studies suggested that adrenergic stress results in compartmental redistribution of T-lymphocytes in vivo ${ }^{24}$. It is also known that epinephrine could be responsible for immunosuppression and inhibition of lymphocyte activation once it can increase cortisol production $^{25}$. Firing of neurons in the locus ceruleus leads to the activation of nerve cells in the paraventricular nucleus of the hypothalamus that secrete corticotropin-releasing hormone (CRH). This yields the release of ACTH by pituitary corticotrophs and subsequent corticosteroid production by the adrenal corte ${ }^{24}$. Subsequently changes in the adhesion molecules could be observed. Even though epinephrine can be associated with decreased lymphocyte activation, in the present study, no changes in the expression of CD62L and CD45RA could be observed with the addition of this amine.

There is paucity of data addressing the relationship of serotonin and lymphocyte migration in the literature. The study of Yamaki et al. suggests that serotonin was less active than exogenous histamine in evoking venular polimorphonuclear leukocyte accumulation ${ }^{26}$. Our data suggest that the regulation of CD45RA and CD62L is not related to the presence of serotonin or epinephrine, but depends on other mechanisms, such as the presence of IL-2 and the expression of IL-2R.

The present study has some limitations that should be aknowledged. Firstly, in vitro measures of immune function with the cultured cells were not performed, so there are no data related to proliferation lymphocyte. Also unstimulated cells were not analysed and the effects on the adhesion molecules could be related to the activation status of the cells.

Our data suggest that IL-2 is involved in downregulation of L-selectin. Even though this result is in agreement with our previous clinical study, we could not demonstrate that other components involved in panic disorder as epinephrine and serotonin are responsible for the changes observed in lymphocyte phenotype expression. It is suggested that the increased expression of CD62L and CD45RA lymphocytes in patients with panic disorder compared to controls are related to decrease cellular activation (demonstrated by decreased IL-2 production). As corticosteroids are potent inhibitors of IL-2 production, increased levels of cortisol in vivo could lead to diminished IL-2 production into memory lymphocytes following sensitization in vivo. The lymphocytes from panic patients could be less able to produce cytokines because these patients showed increased plasma cortisol (potent IL-2 production inhibitor) ${ }^{19}$ as it was demonstrated in the previous study. Cortisol could also drive peripheral blood activated lymphocytes to cell death by apoptosis. This model demonstrated that there is an interaction between the nervous and the immune system, but future research should be addressed to study the effects of neurotransmitters, immune system and some hormones in psychiatric disorders. 


\section{REFERENCES}

1. Ader R, Cohen N. Psychoneuroimmunology. 2.Ed. San Diego: Academic Press, 1991.

2. Coryell W, Noyes R, Schelechte J. The significance of HPA axis disturbance in panic disorder. Biol Psychiatry 1989;25:989-1002.

3. Avery D, Osgood T, Ishiki D, Wilson L, Kenny M, Dunner D. The DST in outpatients with generalized anxiety disorder, panic disorder or primary affective disorder. Am J Psychiatry 1985;142:844-848.

4. Blalock JE. The syntax of immune-neuroendocrine communication. Immunol Today 1994; 15:504-511.

5. Rapaport MH, Stein MB. Serum cytokine and soluble interleukin-2 receptor in patients with panic disorder. Anxiety 1994;1:22-25.

6. McDaniel JS, Risby ED, Stipetic M, Jewart RD, Claude J. Natural killer cell activity in patients with panic disorder. Anxiety 1994/1995;1:192-195.

7. Surman OS, Williams J, Sheehan DV, Strom TB, Jones KL, Coleman J. Immunological response to stress in agoraphobia and panic attacks. Biol Psychiatry 1986;21:768-774.

8. Weizman R, Laor N, Wiener Z, Wolmer L, Bessler H. Cytokine production in panic disorder patients. Clin Neuropharmacol 1999; 22:107-109.

9. Pollack MH, Otto MW, Worthington JJ, Manfro GG, Wolkow W R. Sertraline in the treatment of panic disorder: a flexible dose multicenter srudy. Arch Gen Psychiatry1998;55:1010-1016.

10. Charney D, Woods SW, Goodman WK, Heninger GR. Neurobiological mechanisms of panic anxiety: biochemical and behavioral correlates of yohimbine-induced panic attacks. Am J Psychiatry 1987;144:1030-1036.

11. Springer TA. Traffic signals for lymphocytes recirculation and leucocyte emigration: the multistep paradigm. Cell 1994;76:301-314.

12. Jung TM, Gallatin WM, Weissmen IL, Dailey MO. Down-regulation of homing receptor after T-cell activation. J Immunol 1988;141:4110-4117.

13. Manfro GG, Pollack MH, Otto MW, et al. Cell-surface expression of L-selectin (CD62L) by blood lymphocytes: correlates with affective parameters and severity of panic disorder. Depress Anxiety 2000;11:31-37.
14. Urdal DL, March CJ, Gillis S, Larsen A, Dower SK. Purification and chemical characterization of the receptor for interleukin-2 from activated human T-lymphocytes and from human T-cell lymphoma cell line. Proc Natl Acad Sci USA 1984;81:6481-6485.

15. Camerini DS, James SP, Stamenkovic I, Seed B. Leu8/TQ1 is the human equivalent of the MEL-14 lymph node homing receptor. Nature 1989;342:78-82.

16. Kan EAR, Wang CY, Wang LC, Evans RL. Non-covalently bonded subunits of 22 and $28 \mathrm{Kd}$ are rapidly internalized by T-cells reacted with anti-Leu4 antibody. J Immunol 1983; 131:536-539.

17. Rupprecht R, Wodarrz $\mathrm{P}$, Kornhuber J, et al. In vivo and in vitro effects of glucocorticoids on lymphocyte proliferation in depression. Eur Arch Psychiatry Clin Neurosci 1991; 241:35-40.

18. Rodberg G, Kradin R. Epinephrine promotes T-lymphocyte traffic to the lung. Am J Respir Crit Care Med 1994;49:A12.

19. Cantrell DA, Smith KA. The interleukin-2 T-cell system: a new cell growth model. Science 1984;224:1312-1326.

20. Gillis S, Crabtree GR, Smith KA. Glucocorticoid-induced inhibition of $T$ cell growth factor production: I. The effect on mitogen-induced lymphocyte proliferation. J Immunol 1979;123:1624-1631.

21. Kroemer G. The pharmacology of T cell apoptosis. Am J Respir Crit Care Med 1995;58:211-296.

22. Clement L, Yamashita N, Martin AM. The functionally distinct subpopulations of human CD4+ helper/inducer T lymphocytes defined by anti-CD45R antibodies derive sequentially from a differentiation pathway that is regulated by activation-dependent post-thymic differentiation. J Immunol 1988;141:1464-1470.

23. Jilma B, Eichler HG, Stohlawtz P, et al. Effects of exercise on circulating vascular adhesion in healthy men. Immunobiology 1997;197:505-512.

24. Ottaway CA, Husband AJ. The influence of neuroendocrine pathway on lymphocyte migration. Immunol Today 1994;15:511-517.

25. Chambers D, Cohen R, Perlman R. Neuroimmune modulation: signal transduction and cathecolamine. Neurochem Int 1993;22:95-110.

26. YamakiK, Thorlacius H, XieX, Lindbom L, HedqvistP, Raud J. Characteristics of histamine-induced leukocyte rolling in the undisturbed microcircualtion of the rat mesentery. Br J Pharmacol 1998; 123:390-399. 